\title{
Warming permafrost and active layer variability at Cime Bianche, Western European Alps
}

\author{
P. Pogliotti ${ }^{1}$, M. Guglielmin ${ }^{2}$, E. Cremonese ${ }^{1}$, U. Morra di Cella ${ }^{1}$, G. Filippa ${ }^{1}$, C. Pellet $^{3}$, and C. Hauck \\ ${ }^{1}$ Environmental Protection Agency of Valle d'Aosta, Saint Christophe, Italy \\ ${ }^{2}$ Department of Theoretical and Applied Sciences, Insubria University, Varese, Italy \\ ${ }^{3}$ Department of Geosciences, University of Fribourg, Fribourg, Switzerland \\ Correspondence to: P. Pogliotti (paolo.pogliotti@gmail.com)
}

Received: 17 June 2014 - Published in The Cryosphere Discuss.: 21 July 2014

Revised: 21 February 2015 - Accepted: 10 March 2015 - Published: 8 April 2015

\begin{abstract}
The objective of this paper is to provide a first synthesis on the state and recent evolution of permafrost at the monitoring site of Cime Bianche (3100 m a.s.l.) on the Italian side of the Western Alps. The analysis is based on 7 years of ground temperature observations in two boreholes and seven surface points. The analysis aims to quantify the spatial and temporal variability of ground surface temperature in relation to snow cover, the small-scale spatial variability of the active layer thickness and current temperature trends in deep permafrost.

Results show that the heterogeneity of snow cover thickness, both in space and time, is the main factor controlling ground surface temperatures and leads to a mean range of spatial variability $\left(2.5 \pm 0.1^{\circ} \mathrm{C}\right)$ which far exceeds the mean range of observed inter-annual variability $\left(1.6 \pm 0.1^{\circ} \mathrm{C}\right)$. The active layer thickness measured in two boreholes at a distance of $30 \mathrm{~m}$ shows a mean difference of $2.0 \pm 0.1 \mathrm{~m}$ with the active layer of one borehole consistently deeper. As revealed by temperature analysis and geophysical soundings, such a difference is mainly driven by the ice/water content in the sub-surface and not by the snow cover regimes. The analysis of deep temperature time series reveals that permafrost is warming. The detected trends are statistically significant starting from a depth below $8 \mathrm{~m}$ with warming rates between 0.1 and $0.01^{\circ} \mathrm{C} \mathrm{yr}^{-1}$.
\end{abstract}

\section{Introduction}

The study of permafrost in mountain regions has become relevant in view of ongoing climate changes (Stoffel et al., 2014; Allen and Huggel, 2013; Etzelmüller, 2013; Fischer et al., 2013; Haeberli, 2013; Harris et al., 2009; Gruber and Haeberli, 2007; Gruber, 2004). Although permafrost warming and increasing active layer thickness (ALT) has been observed worldwide (Harris, 2003; Smith et al., 2010; Romanovsky et al., 2010; Wu and Zhang, 2008; Christiansen et al., 2010; Guglielmin and Cannone, 2012; Guglielmin et al., 2014a), in mountain areas the complexity of topography, ground surface type, snow cover distribution, subsurface hydrology and geology strongly influence the thermal regime of mountain permafrost (Gruber and Haeberli, 2009), altering the response to changing environmental conditions.

For monitoring the huge spatial variability of mountain permafrost, a number of monitoring sites has been established through the Alps during the last years (e.g., Cremonese et al., 2011). At present the collection of temperatures in boreholes provides the best direct evidence of permafrost state and evolution. Nevertheless, the combination of geophysical methods and thermal monitoring is particularly suitable for long-term monitoring of mountain permafrost because it provides crucial information on ground ice/water content and structure (e.g., Hilbich et al., 2008; Haeberli et al., 2010; PERMOS, 2013). The site of Cime Bianche has been designed with the main objective of monitoring the spatial variability of mountain permafrost. Moreover Cime Bianche site is a permanent observatory in the southern side of the European Alps, a region where permafrost observa- 
tions are more sparse and younger compared to the northern side (e.g., Cremonese et al., 2011), and where significant climatological differences occur (e.g., Frei and Schär, 1998; Evans and Cox, 2005).

At Cime Bianche, the spatial variability of ground surface temperature (GST) is measured because it has crucial implications on the initialization, calibration and validation of numerical models (e.g., Guglielmin et al., 2003; Noetzli and Gruber, 2009; Hipp et al., 2014), and it is often used as an indicator of permafrost occurrence. One of the main challenges in the study of GST variability is the quantification of the thermal effect of snow cover given the influence that it can have on thermal regime trough different processes (Zhang, 2005; Luetschg et al., 2008; Guglielmin et al., 2014b). On gentle slopes, snow cover mostly causes a net increase of mean annual ground temperature due to the insulating effect during winter, but timing of onset and meltout, duration, thickness and interaction with ground surface characteristics strongly control the local magnitude of this effect (Hoelzle et al., 2003; Brenning et al., 2005; Gruber and Hoelzle, 2008; Pogliotti, 2010; Gubler et al., 2011; Rödder and Kneisel, 2012). Although a number of studies focused on snow-GST interaction exists (e.g., Zhang, 2005, for a review), little is known on its spatial and temporal variability especially over complex alpine terrains.

Beside the GST, the active layer thickness is also measured at Cime Bianche. The World Meteorological Organization recognizes permafrost and active layer as one of the essential climate variables selected for quantifying the impacts of climate change (e.g., Harris and Haeberli, 2001). In the Alps, the active layer is of particular interest because it directly affects slope processes (e.g., Fischer et al., 2012) and infrastructures stability (e.g., Bommer et al., 2010; Springman and Arenson, 2008). The active layer dynamics are controlled by a number of variables such as air temperature, solar radiation, topography, ground surface characteristics, ground ice/water content and the timing, distribution and physical characteristics of the snow cover (Zhang, 2005; Luetschg et al., 2008; Scherler et al., 2010; Wollschläger et al., 2010; Zenklusen Mutter and Phillips, 2012). As a consequence, the active layer thickness has an high spatial and temporal variability (Anisimov et al., 2002; Wright et al., 2009) which in the Alps may occur at very small scale.

Compared to the active layer which responds more to short-term variations like seasonal snow and air temperature conditions, the deep (10 to $200 \mathrm{~m}$ ) thermal regime of permafrost reacts to long-term changes in climate (Beltrami, 2002). The deep permafrost temperature regime is a sensitive indicator of the long-term climate variability and changes of the surface energy balance (Romanovsky et al., 2002). The trend analysis of deep temperature time series allows the detection of signals of past and ongoing changes of permafrost (e.g., Isaksen et al., 2001).

The overall objective of this paper is to provide a first synthesis on the state and recent evolution of permafrost at Cime

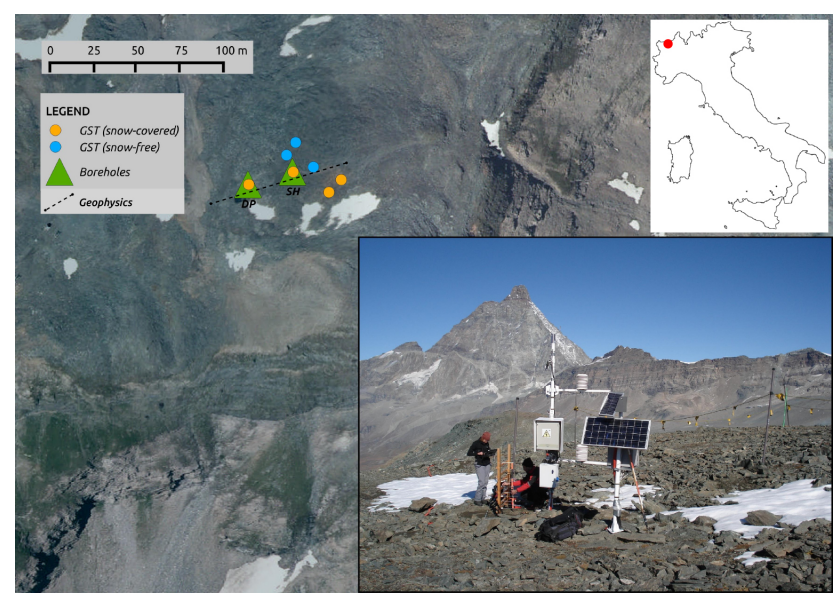

Figure 1. Overview of the Cime Bianche monitoring site.

Bianche. In particular we present (i) the spatial and temporal variability of GST and its relation with snow cover (ii) the small-scale $(30 \mathrm{~m})$ ALT differences and (iii) the warming trend of deep permafrost temperature.

\section{Data and methods}

\subsection{Site description}

The Cime Bianche monitoring site is located in the Western Alps at the head of the Valtournenche valley (Valle d'Aosta, Italy, $45^{\circ} 55^{\prime} \mathrm{N}-7^{\circ} 41^{\prime} \mathrm{E}$ ) on the Italian side of the Matterhorn, at $3100 \mathrm{~m}$ a.s.l. (Fig. 1). The site is located on a small plateau slightly westward, with degrading characterized by terracettes, convexities and depressions that result in a high spatial variability of snow cover thickness during winter.

The bedrock lithology is homogeneous, mainly consisting of garnetiferous micaschists and calcschists belonging to the upper part of the Zermatt-Saas ophiolite complex (Dal Piaz, 1992). The bedrock surface is highly weathered and fractured, locally resulting in a cover of coarse-debris deposits with a thickness ranging from few centimeters to a couple of meters. The presence of small landforms like gelifluction lobes (between 0.6 and almost $5 \mathrm{~m}$ in length) and sorted polygons of fine material (with diameters ranging between 0.6 and $3.4 \mathrm{~m}$ ) suggests the presence of permafrost.

The climate of the area is slightly continental. The longterm mean annual precipitation is reported to be about $1000 \mathrm{~mm} \mathrm{yr}^{-1}$ for the period 1931-1996 (Mercalli and Cat Berro, 2003) while the in situ records show a mean of $1200 \mathrm{~mm} \mathrm{yr}^{-1}$ for the period 2010-2013. The mean annual air temperature (MAAT) is about $-3.2{ }^{\circ} \mathrm{C}$ (mean 19512011). Mean monthly air temperatures are positive from June to September, while February and July are, respectively, the coldest and the warmest months. The site is very windy and mainly influenced by NE-NW air masses. The wind action 
strongly contributes to the high spatial variability of snow cover thickness.

Permafrost research in the area started in the late 1990s (Guglielmin and Vannuzzo, 1995) with repeated campaigns of measurements of the bottom temperature of snow (BTS) and glaciological observations showing that the monitoring site was probably ice covered during the climax of the Little Ice Age. In 2003, as a preliminary investigations for site selection, the potential permafrost occurrence in the area was assessed using results from BTS, vertical electrical soundings and ERT (electrical resistivity tomography) and the application of numerical models like Permakart (Keller, 1992) and Permaclim (Guglielmin et al., 2003).

\subsection{Instrumentation}

The site instrumentation started in 2005 and has been progressively upgraded during the following years. The current setting is nearly unchanged since August 2008 and consists of two boreholes, a spatial grid of ground surface temperatures measures and an automatic weather station (AWS).

\subsubsection{Boreholes}

A deep (DP) and a shallow (SH) borehole, reaching a depth of 41 and $6 \mathrm{~m}$, respectively, located at a distance of about $30 \mathrm{~m}$ (Fig. 1), have been drilled in 2004 with core-destruction method. Both boreholes are $127 \mathrm{~mm}$ in diameter with a $60 \mathrm{~mm}$ sealed PVC pipe for sensor housing. The boreholes are equipped with thermistor chains based on resistors type YSI 44031 (resolution $0.01^{\circ} \mathrm{C}$, absolute accuracy $\pm 0.1^{\circ} \mathrm{C}$ ). The entire setup (thermistor chains attached to the data logger) have been calibrated by the manufacturer before the installation. Sensors depths in meters from the surface are 0.02 , $0.3,0.6,1,1.6,2,2.3,2.6,3,3.3,3.6,4,4.6,5.9$ for $\mathrm{SH}$ and $0.02,0.3,0.6,1,1.6,2,2.6,3,3.6,4,6,8,10,12,14,15$, $16,17,18,20,25,30,35,40,41$ for DP. In each borehole, the shallower sensors $(0.02$ and $0.3 \mathrm{~m})$ are cabled on two independent chains and are used to measure the ground surface temperature outside the PVC tube in order to avoid the thermal disturbance of the casing. Temperatures are sampled every $10 \mathrm{~min}$ and recorded by a Campbell Scientific CR800 data logger. The system is equipped with a GPRS module for daily remote data transmission.

\subsubsection{Ground surface temperature grid (GSTgrid)}

A small grid $(40 \mathrm{~m} \times 10 \mathrm{~m})$ is used for monitoring the spatial variability of GST. The grid consists of five nodes: four at the corners and one in the center (Fig. 1). Each node is equipped with two platinum resistors, PT1000 (resolution $0.01{ }^{\circ} \mathrm{C}$, accuracy $\pm 0.1{ }^{\circ} \mathrm{C}$ ), buried in the ground at depths of 0.02 and $0.3 \mathrm{~m}$ (according to Guglielmin, 2006). Ground temperatures are recorded hourly by a Geoprecision D-Log 12 data logger.

For the analysis, GST measured at the two boreholes is also included; thus data from seven nodes are used for the analysis. Ground surface at each node is mainly characterized by coarse debris with a fine matrix of coarse sand and fine gravel. At each node, the sensors are placed in the matrix thus local ground conditions are nearly homogeneous between all nodes. In contrast, snow cover depth and duration sharply differ across the grid nodes. For this reason, based on field observations and temperature time series analysis (Schmid et al., 2012) the data set is divided in snowfree and snow-covered nodes. The first group includes three nodes characterized by shallow or intermittent winter snow cover, while the latter group includes four nodes that clearly show a long lasting deep snow cover damping temperature oscillations during winter (Fig. 1).

\subsubsection{Automatic weather station}

An AWS has been installed just above the borehole SH since 2006. Air temperature and relative humidity, atmospheric pressure, wind speed and direction, incoming and outgoing short- and long-wave solar radiation and snow depth are recorded every 10 min by a Campbell Scientific CR3000 data logger. The system is equipped with a GPRS module for the daily remote data transmission. In September 2011 a second snow depth sensor was installed in the surroundings of the DP borehole. Finally, solid and liquid precipitation has been measured since January 2009 by an OTT Pluvio ${ }^{2}$ system.

\subsection{Data analysis}

This section reports a short description of the methods used for the calculations of synthesis parameters considered in this study.

MAGT is the mean annual ground temperature at a specific depth (m) (e.g., $\left.\mathrm{MAGT}_{10}\right)$.

MAGST is the mean annual ground surface temperature.

ALT is the active layer thickness defined as the maximum depth $(\mathrm{m})$ reached by the $0^{\circ} \mathrm{C}$ isotherm at the end of the warm season. It is calculated considering the maximum daily temperature at each sensor depth and interpolating between the deepest sensor with positive value and the sensor beneath. The maximum of the resulting vector and the corresponding day are named ALT and ALTday, respectively. This procedure is applied on the warmest period of the year, here fixed from 1 August to 30 November. The uncertainty of ALT estimation is evaluated considering the amplitude of thermistors noise (inferred from calibration of the manufacturer) and the interpolation distance between the sensors. Considering these factors, the uncertainty of ALT estimation is $\pm 0.15 \mathrm{~m}$ in borehole $\mathrm{SH}$ and $\pm 0.2 \mathrm{~m}$ in borehole DP.

TTOP is the MAGT at the top of the permafrost table (Smith and Riseborough, 1996). It is calculated by interpolation of the MAGT at depth of the ALT that is considering the first sensors above and below the ALT.

THO is the thermal offset within the active layer and is computed as TTOP-MAGST (Burn and Smith, 1988). 


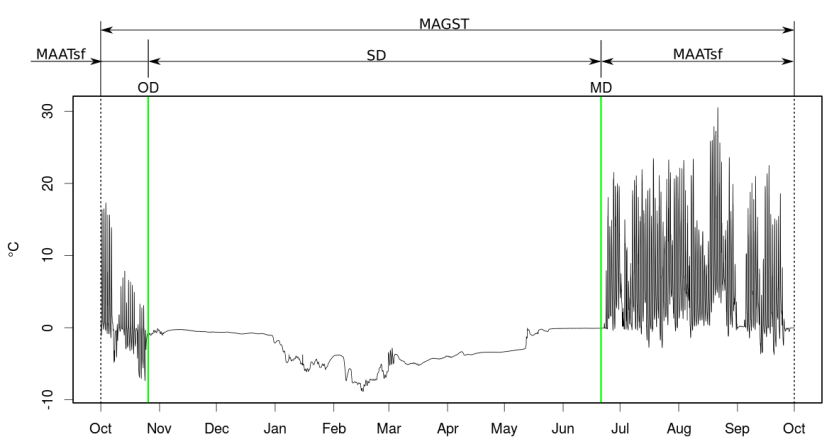

Figure 2. Example of detection of snow cover duration from GST time series with the method of Schmid et al. (2012). OD is the onset date of snow; MD is the melting date of snow. The periods used for the calculation of MAGST, SD and MAATsf are represented by the scheme on top.

Zero annual amplitude oscillation (ZAA) is the depth beneath which there is almost no annual fluctuation (AF) in ground temperature, nominally smaller than $0.1{ }^{\circ} \mathrm{C}$ (van Everdingen, 2005). The AF is calculated at each sensor depth as the difference between annual maximum and annual minimum of the mean daily temperatures. The ZAA is calculated by interpolation between the deepest sensor with AF greater than $0.1^{\circ} \mathrm{C}$ and the sensor beneath. When necessary, a moving average, with a window of 360 days, is applied on deep nodes data (below $8 \mathrm{~m}$ ) before daily aggregation to remove electrical noise $\left( \pm 0.01{ }^{\circ} \mathrm{C}\right)$.

All the parameters listed above, with the exception of ALT, are computed considering the hydrological year (beginning 1 October) as a reference period. All the analyses are performed with the free statistical software R (R Core Team, 2014). When appropriate, the variability of the results is expressed in terms of standard error ( $\mathrm{se}=\mathrm{sd} / \sqrt{n}$, where se is standard error, sd is standard deviation and $n$ is the sample size).

\subsection{Snow cover duration and snow-free days}

In order to investigate the effect of snow cover duration and air temperature on MAGST, the method of Schmid et al. (2012) is applied on snow-covered nodes using the sensors at $0.02 \mathrm{~m}$. This method allows us to infer the date of snow onset (OD) and the date of snow melt (MD) from the amplitude of ground temperature oscillation. Subsequently, starting from $\mathrm{OD}$ and $\mathrm{MD}$, it is possible to calculate (i) the duration of snow cover (SD, Fig. 2) as the number of days between OD and MD and (ii) the number of snow-free days as the sum of remaining days of autumn and summer. The latter period is used as reference for calculating the mean annual air temperature of snow-free days (MAATsf, Fig. 2).

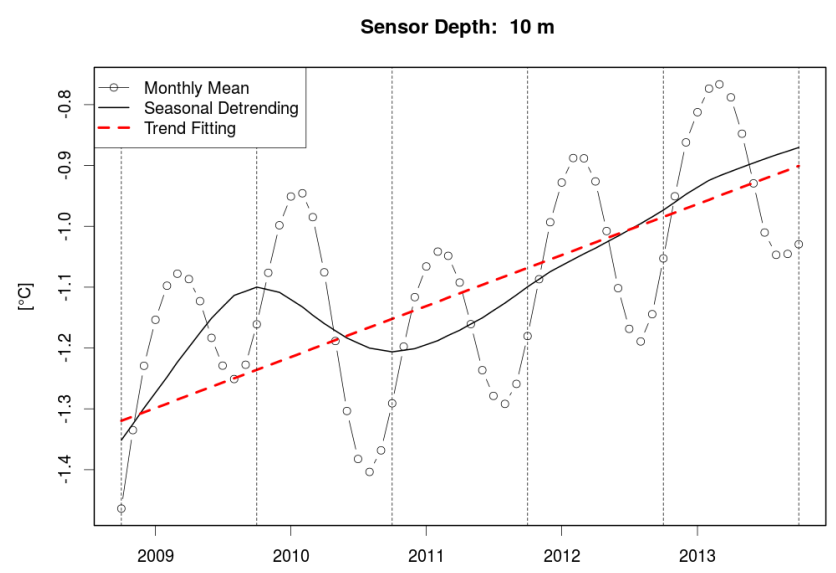

Figure 3. Methodological steps of trend analysis. Step 1: monthly aggregation (thin black line with circles). Step 2: seasonal detrending (thick black line). Step 3: trend fitting (dashed red line). Vertical dashed lines represents 1 October, materializing the limits of the hydrological years.

\subsection{Trend analysis}

In order to look for linear trends that might reflect warming, two non-parametric methods are applied to borehole temperatures: Mann-Kendall test (MK) (Mann, 1945; Kendall, 1948) and Sen's slope estimator (SS) (Sen, 1968). These methods are commonly used to assess trends and related significance levels in hydro-meteorological time series such as water quality, stream flow, temperature and precipitation (e.g., Gocic and Trajkovic, 2013; Kousari et al., 2013). The reason for using non-parametric statistical tests is that they are more suitable for non-normally distributed data and are not sensitive to outliers or abrupt changes.

The procedure chosen includes (i) the pre-whitening of the data to remove the lag-1 autocorrelation components as recommended by von Storch and Navarra (1999) (see also Hamed, 2009 and Bence, 1995), (ii) the fitting of the trend's slope with SS and (iii) the testing of trend significance level ( $p$ value) with MK. Such a procedure is implemented in the R package zyp (Bronaugh et al., 2013).

Given the short climatological time span of the borehole observations, a seasonal detrending is recommended, as suggested by Helsel and Hirsch (1992), for better discerning the long-term linear trend over time. Thus, a seasonal decomposition based on loess smoother (Cleveland, 1979; Cleveland et al., 1990) is applied to the monthly aggregated time series of each borehole before applying SS and MK (Fig. 3). Such a seasonal detrending method is implemented by the $\mathrm{R}$ function stl (R Core Team, 2014).

\subsection{Geophysics}

At the end of summer 2013, two geophysical surveys have been realized with the objective to assess the composition of 
the subsurface. A first, explorative geoelectric (ERT) profile was performed on 16 August 2013 and repeated on 9 October 2013 in combination with one refraction seismic tomography (RST) along the same line (see Fig. 1). Combining refraction seismic and ERT measurements enables us to unambiguously identify the subsurface materials in the ground. Due to very different specific resistivities, ERT is best suited to differentiate between ice and water, whereas the distinction between air and ice can more easily be accomplished by RST because of large contrasts between their respective $p$ wave velocities.

\subsubsection{Electrical Resistivity Tomography}

A $94 \mathrm{~m}$ long electrode array composed of 48 electrodes with $2 \mathrm{~m}$ spacing was installed along a straight line less than $2 \mathrm{~m}$ away from the two boreholes (Fig. 1). Current was injected using varying electrode pairs, and the resulting potential differences were automatically measured by a Syscal (Iris Instruments) for each quadrupole possible with the WennerSchlumberger configuration (529 measurements, 23 depth levels). The electrode locations were marked with spray paint and a number of electrodes were left on site to facilitate further measurements.

The measured apparent resistivity data sets were then inverted using the RES2DINV software (Geotomosoft, 2014) with the following setup. A robust inversion constraint was applied to avoid unrealistic smoothing of the calculated specific resistivities. Additionally, the depth of the model layers was increased by a factor 1.5 and an extended model was used to match the model grid of the corresponding seismic inversion. Note that for geometric reasons, the two lower corners of the resulting tomograms have very low sensitivity to the obtained data and should not be over-interpreted. Finally, a time-lapse inversion scheme was applied to the two ERT data sets, yielding the percentage of resistivity change from the first measurements to the second. Here, an unconstraint inversion was chosen, meaning that the ERT measurements were inverted independently.

\subsubsection{Refraction seismic tomography}

The measurements were conducted using a Geode seismometer (Geometrics) and 24 geophones placed with $4 \mathrm{~m}$ spacing. A seismic signal was generated in-between every second geophone pair by repeatedly hitting a steel plate with a sledge hammer. To improve the signal-to-noise ratio, the signal was stacked at least 15 times at each location. Two additional offset shot points were measured $(3 \mathrm{~m}$ before the first geophone and $6 \mathrm{~m}$ beyond the last one) in order to maximize the spatial resolution and match the ERT profile length and depth of investigation.

The first arrivals of the seismic $p$ wave were manually picked for each seismogram using the software REFLEXW (Sandmeier, 2014). A simultaneous iterative reconstruction

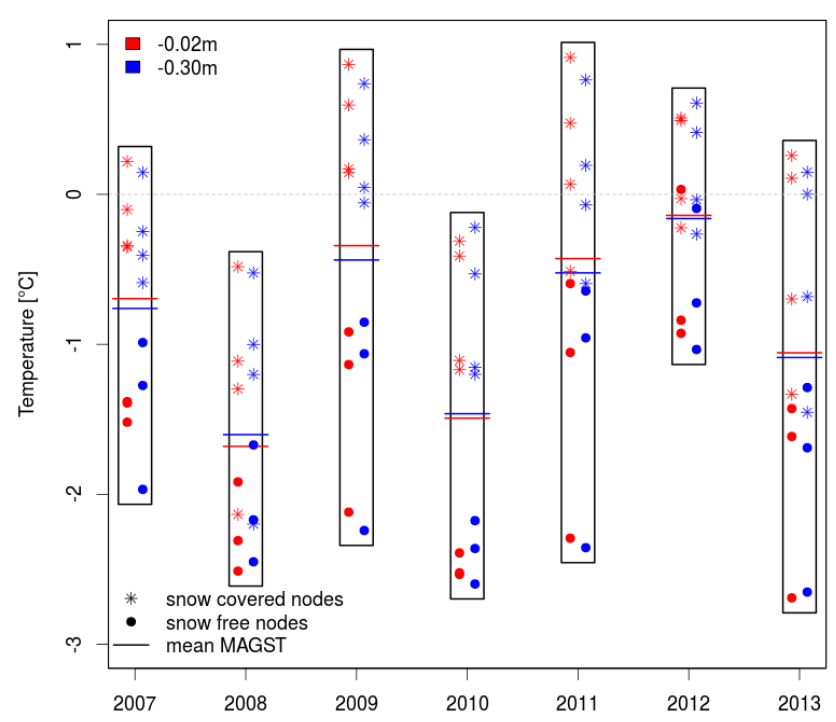

Figure 4. Mean annual ground surface temperatures at depths of $0.02 \mathrm{~m}$ (red) and $0.3 \mathrm{~m}$ (blue). Star symbols indicate snow-covered nodes, while bullets indicate snow-free nodes. The horizontal lines indicate the mean MAGST for each year and each depth. Black rectangles are used to highlight the min-max envelope to facilitate the inter-annual comparison.

technique algorithm was then used to reconstruct a 2-D tomogram of $p$ wave velocity distribution based on the obtained travel times. Starting from a synthetic model, the travel times are calculated and compared to the measured ones. The model is then updated iteratively by minimizing the residuals between measured and calculated travel times.

\section{Results}

\subsection{Ground surface temperatures}

Figure 4 shows MAGST at 0.02 and $0.3 \mathrm{~m}$ on the seven GST nodes. Some years (e.g., 2009, 2011, 2013) show a MAGST spatial variability, evaluated as the range of MAGST measured in all nodes and greater than $3^{\circ} \mathrm{C}$, that clearly exceeds the inter-annual variability. In general, considering all 7 years, we observed that mean spatial variability $\left(2.5 \pm 0.1^{\circ} \mathrm{C}\right)$ is greater than mean inter-annual variability $\left(1.6 \pm 0.1^{\circ} \mathrm{C}\right)$. The results are similar at both depth. The difference between MAGST measured at 0.02 and $0.3 \mathrm{~m}$ is, on average, $0.4 \pm 0.1^{\circ} \mathrm{C}$, with deeper sensors usually warmer than the shallower ones. On average, the thermal offset due to snow cover is about $1.5 \pm 0.2^{\circ} \mathrm{C}$ with snow-covered nodes being warmer than snow-free nodes. These observations confirm that the warming and cooling effects of, respectively, a thick and thin snow cover (Zhang, 2005; Pogliotti, 2010) can coexist over short distances $(<50 \mathrm{~m})$ and lead to high spatial variability of the GST. 

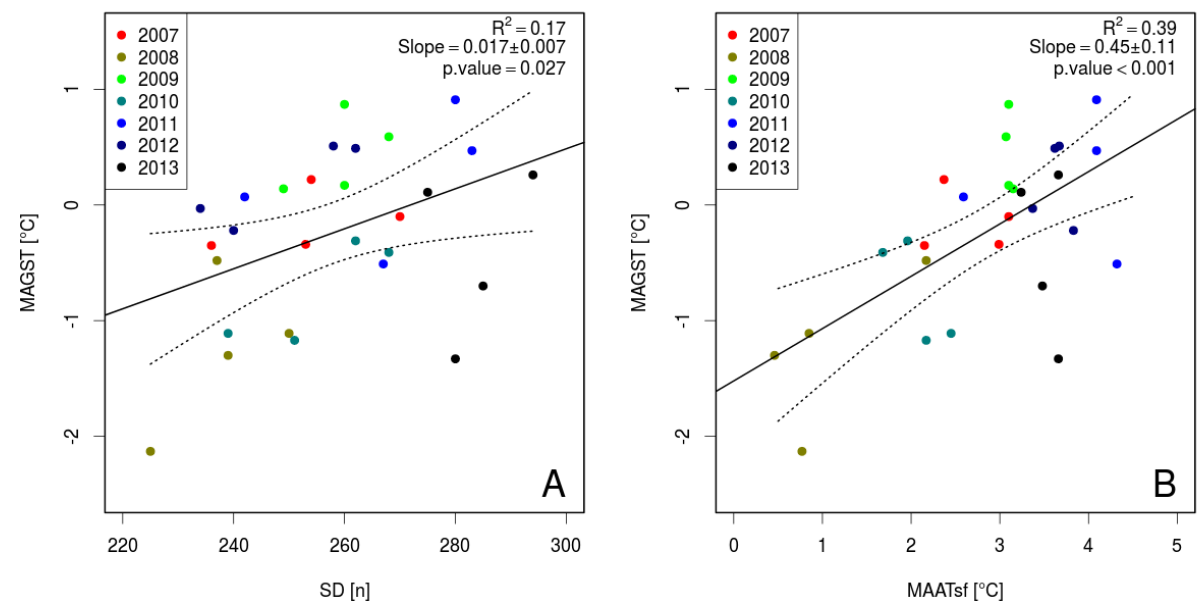

Figure 5. Scatterplots of SD (a) and MAATsf (b) against MAGST. The solid line represents the linear fit while the dotted lines are the confidence intervals. The metrics of the fitting are also reported.

The duration of snow (SD) on snow-covered nodes is on average $270 \pm 6$ days with a mean range of spatial variability of 28 days and a mean range of inter-annual variability of 48 days. To disentangle the influence of snow and air temperature on surface temperature in snow-covered nodes, we tested the relationship between MAGST and MAAT and between MAATsf and SD. We found no significant correlation between MAGST and MAAT. Figure 5 shows the scatterplot comparing SD (A), MAATsf (B) and MAGST: MAGST is significantly correlated to both SD $(p<0.05)$ and MAATsf $(p<0.001)$, with the latter explaining the higher portion of variance $\left(R^{2}=0.39\right)$. Being computed on snow-free days, MAATsf is mainly controlled by air temperature but partially also by the duration of snow cover, therefore integrating the relative contribution of both components (snow duration and air temperature) on MAGST.

\subsection{Active layer}

Table 1 summarizes the active layer parameters observed in the two boreholes. Since August 2008 data are available at both SH and DP boreholes, results of ALT can be compared over 6 years while MAGST, TTOP and THO over 5 years (shaded rows in Table 1). Missing values (column \% NA) in both boreholes are lower than $4 \%$ in all years.

ALT is the parameter showing the greater difference between the two boreholes with a mean of $2.7 \pm 0.3 \mathrm{~m}$ in SH and $4.7 \pm 0.2 \mathrm{~m}$ in DP. The mean inter-annual difference of ALT between the two boreholes is $2.0 \pm 0.1 \mathrm{~m}$, while the mean absolute inter-annual variability of ALT at borehole level is $1.0 \pm 0.1 \mathrm{~m}$. In both boreholes the maximum ALT has been recorded in 2012 and the minimum in 2010. ALT (date) is normally anticipated in DP (except 2013) with differences ranging from a few days (e.g., 2009) to more than 3 weeks (e.g., 2012). The MAGST is on average slightly lower in $\mathrm{SH}$, which normally shows a thinner winter snow

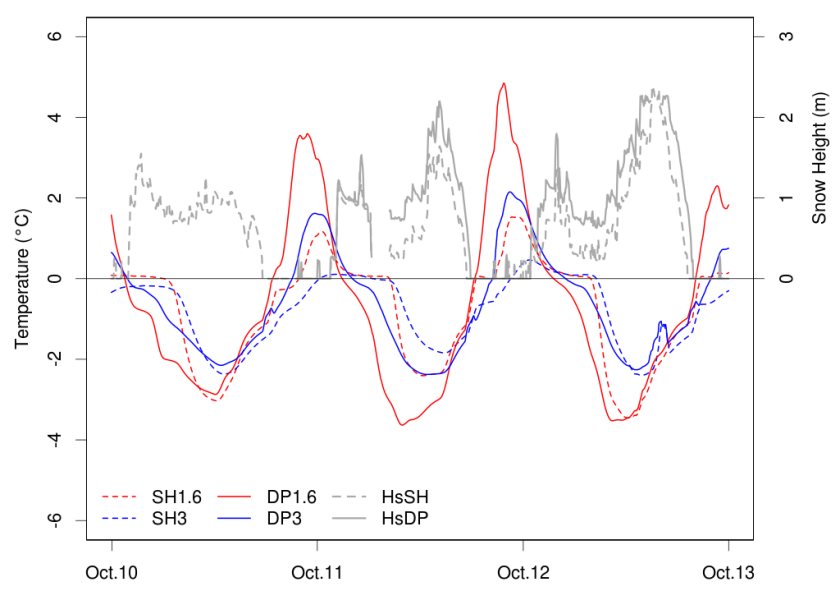

Figure 6. Fluctuations of snow cover thickness (Hs) and ground temperatures (daily mean) at selected depths in the active layers of Cime Bianche from 1 October 2010 to 30 September 2013 determined from borehole temperature data. Lines type: dashed is for SH, solid is for DP. Colors: red is for shallower temperatures $(1.6 \mathrm{~m})$, blu is for deeper temperature $(3 \mathrm{~m})$, grey is for snow.

cover compared to DP (Fig. 6). The TTOP values are very similar, around $-0.9^{\circ} \mathrm{C}$. The THO is negative in both boreholes (except 2013) with a mean value of about $-0.5^{\circ} \mathrm{C}$ in $\mathrm{DP}$ and $-0.3^{\circ} \mathrm{C}$ in $\mathrm{SH}$.

The values of Table 1 show that all the active layer parameters are very similar between the two boreholes with the only exception of ALT, which in DP is nearly double than in SH. To better understand the causes of this difference, the daily mean temperatures at selected depths within the active layer of both boreholes and the corresponding snow cover thickness are compared in Fig. 6. Although a consistently thinner snow depth is recorded on SH compared to DP (mean difference $\sim 41 \pm 14 \mathrm{~cm}$ during the winter sea- 


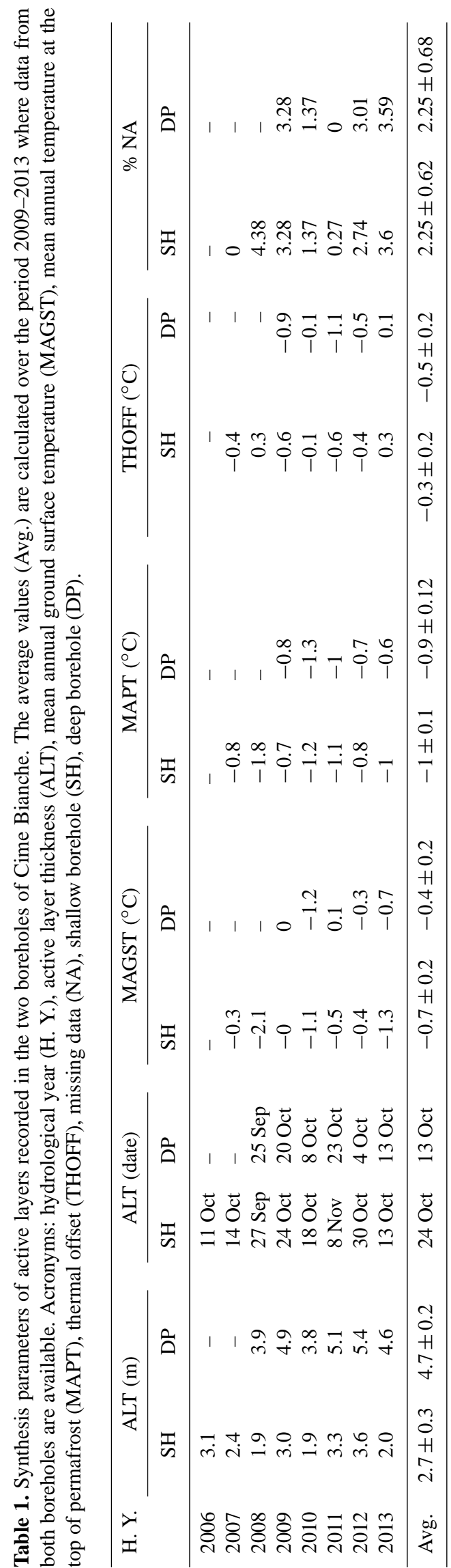

sons 2012 and 2013), the duration of the insulating snow cover is similar ( $250 \pm 16$ days for SH vs. $254 \pm 17$ days for DP) and effectively does not determine a large difference in MAGST (Table 1). Consequently, the snow cover regimes of the two boreholes can be considered equivalent.

For these reasons we hypothesize that ALT difference may be related to a greater ice/water content in $\mathrm{SH}$ compared to DP. This is revealed by the geophysical survey (see Sect. 3.4 and Fig. 9) and can be inferred by temperatures at greater depth. At $1.6 \mathrm{~m}$ (red lines, Fig. 6) a pronounced zero-curtain effect can be observed in SH (dashed lines) twice per year, (i) from snow melt to mid-summer and (ii) from the snow onset to mid-winter, while a similar behavior is missing in DP. The occurrence of the zero-curtain reflects a large consumption of energy, both for ice melting during summer and water freezing during winter, resulting in lower temperatures of $\mathrm{SH}$. Deeper down, the summer heat wave in $\mathrm{SH}$ is further delayed if compared to DP: at $3 \mathrm{~m}$ in SH (dashed blue lines) the zero-curtain effect is almost continuous from late summer to early winter (e.g., in 2010 and 2011), and it is not possible to see a breaking point between melting and freezing processes. Such a behavior is totally missing in DP. It is also interesting to observe that freezing zero-curtain ends nearly contemporary at 1.6 and $3 \mathrm{~m}$ and is followed by a rapid temperature drop.

In conclusion, the ALT at Cime Bianche shows a pronounced spatial variability probably caused by the variability of ice/water content in the sub-surface and associated energy consumption resulting from freezing and melting processes.

\subsection{Permafrost temperature and warming trend}

Due to the small depth reached by the borehole SH, the analysis of permafrost temperature is limited to the borehole DP. Looking at temperature profiles with depth (Fig. 7), the permafrost layer at Cime Bianche has a thickness greater than $40 \mathrm{~m}$ and a mean temperature of about $-1.2^{\circ} \mathrm{C}$. The ZAA varies across years and during the observation period ranged from a minimum of $14.2 \mathrm{~m}$ in 2011 to a maximum of $16.2 \mathrm{~m}$ in 2013 (Table 2). During the observed years, both minimum (solid lines) and maximum (dashed lines) temperature profiles (deeper than $6 \mathrm{~m}$ ) tend to progressively shift toward warmer temperatures (Fig. 7). The only exceptions are represented by the 2011 maximum and the 2009 minimum, with the latter only above $10 \mathrm{~m}$ of depth.

The observed temperature shift is also quantitatively supported by the trend analysis. The analysis was conducted at all depths, but only deeper temperatures (below $8 \mathrm{~m}$ ) show significant trends (Kendall's $p$ value $<0.01$ ). Figure 8 reveals that a pronounced warming rate ranging from $0.1^{\circ} \mathrm{C} \mathrm{yr}^{-1}$ at $8 \mathrm{~m}$ to $0.007^{\circ} \mathrm{C} \mathrm{yr}^{-1}$ at $41 \mathrm{~m}$ can be observed. The upper boundaries of the confidence intervals are systematically unbalanced toward higher values and the lower boundaries are always above zero. This means that, at all depths, the statistical distribution of all possible fitted trends 


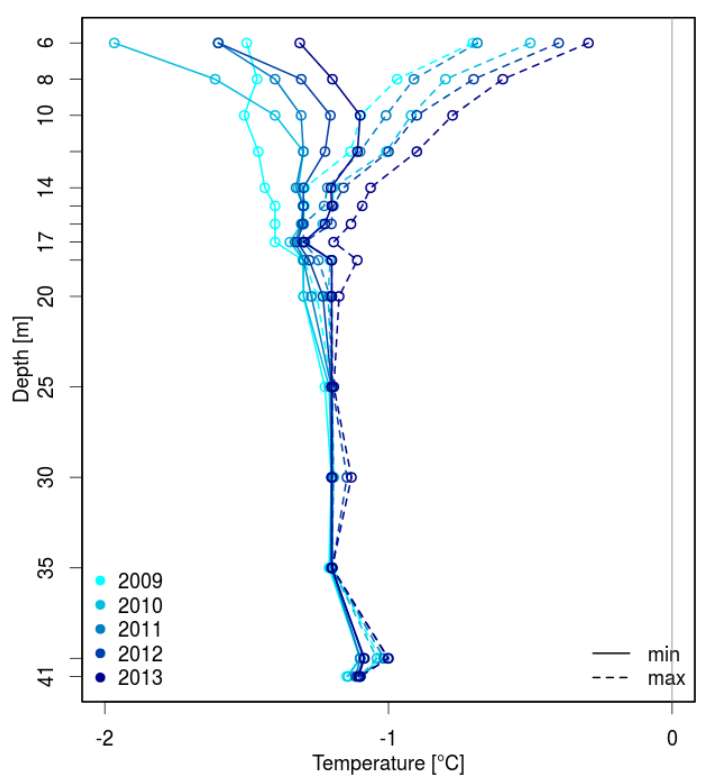

Figure 7. Minimum (solid lines) and maximum (dashed lines) temperature profiles in the borehole DP below $6 \mathrm{~m}$ of depth for the period 2009-2013.

is positively skewed. Based on this analysis, it is concluded that permafrost at Cime Bianche is warming because significant positive warming rates are reported below $8 \mathrm{~m}$.

\subsection{Geophysics}

Figure 9 shows the final distribution of specific resistivity for the two ERT measurements, the percentage of change in the model resistivity between the two time steps and the $p$ wave velocity distribution over the same subsection. Additionally, the surface characteristics and a detailed analysis of the geophysical properties at the two borehole locations (SH and DP, Fig. 10) are included in the analysis.

The overall characteristics of both ERT profiles are very similar (Fig. 9a and b) and can be divided into three main zones: a low resistive layer directly below the surface, varying between $2.5 \mathrm{~m}$ thickness at the top of the slope and $7 \mathrm{~m}$ thickness at the bottom; two high resistive areas with values exceeding $20000 \Omega \mathrm{m}$, located below the superficial layer (from the start of the subsection to the superficial borehole: 0-34 $\mathrm{m}$ and 40-52 $\mathrm{m}$ ); and a less-high resistive area on the lower part of the profile below $5 \mathrm{~m}$ depth.

Comparing the two ERT data sets (cf. also the time-lapse image in Fig. 9c), one can observe a clear increase of the uppermost low resistive layer between August and October which is coherent with a thickening of the active layer observed in the borehole temperature during this period. Another main difference between the two measurements is the apparition of two low resistive zones at 34 and $60 \mathrm{~m}$, visible down to 10 and $15 \mathrm{~m}$ depth, respectively. These areas can also be seen in the ERT tomogram from August but much
Table 2. Interpolated depth of zero annual amplitude oscillation (ZAA) and corresponding mean temperatures in the borehole DP.

\begin{tabular}{ccc}
\hline H. Y. & \multicolumn{2}{c}{ ZAA $\left(\Delta T=0.1^{\circ} \mathrm{C}\right)$} \\
\cline { 2 - 3 } & Depth $(\mathrm{m})$ & Temp. $\left({ }^{\circ} \mathrm{C}\right)$ \\
\hline 2009 & 15.5 & -1.3 \\
2010 & 15.2 & -1.2 \\
2011 & 14.2 & -1.3 \\
2012 & 15.3 & -1.2 \\
2013 & 16.2 & -1.2 \\
\hline Avg. & 15.3 & -1.2 \\
\hline
\end{tabular}

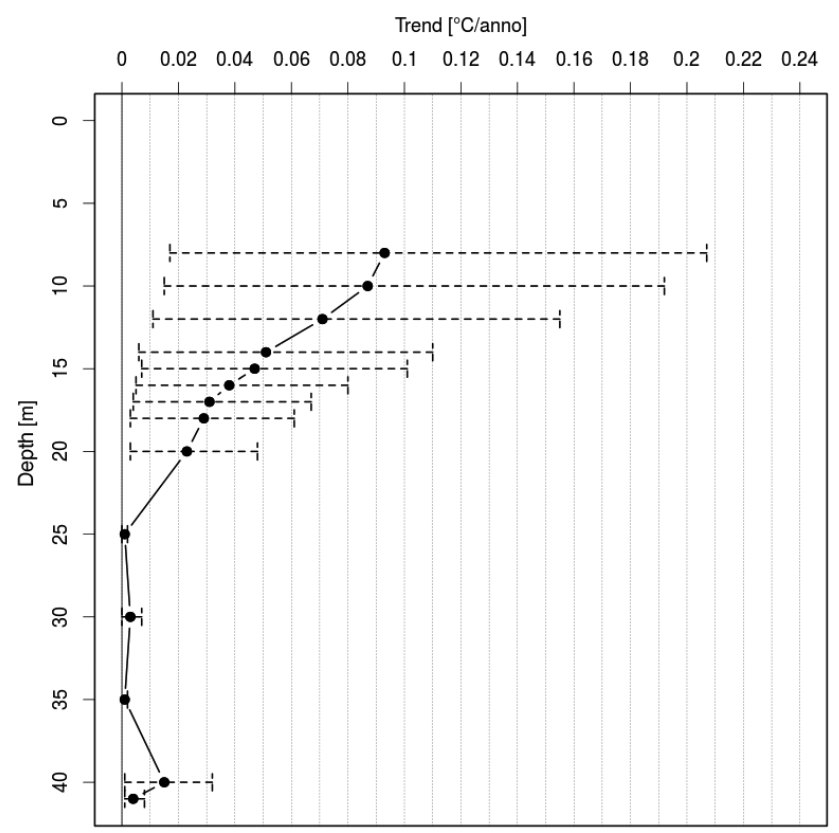

Figure 8. Warming rate calculated over the period 2009-2013 below $8 \mathrm{~m}$ of depth in the borehole DP as a function of depth. Black dots represent linear trends as ${ }^{\circ} \mathrm{Cyr}^{-1}$. The uncertainty of trend values is represented by the dashed bars, which indicate the lower and upper boundaries of the $95 \%$ confidence interval of the fitting model (see Sect. 2.5 for details).

less developed and limited to a few meters. In addition, the very high resistive area located in the upper part of the profile is much smaller and displaced by about $5 \mathrm{~m}$ towards the lower part of the profile in the second measurement.

These changes are clearly visible in blue (increase) and red (decrease) colors in Fig. 9c. As stated before, the two data sets were inverted independently within the time-lapse scheme. A constrained inversion (results not shown here) would yield very similar overall distribution of resistivity changes; the only difference is a much smaller range of values. The large area of resistivity increase, located just above the superficial borehole location and reaching down to the 

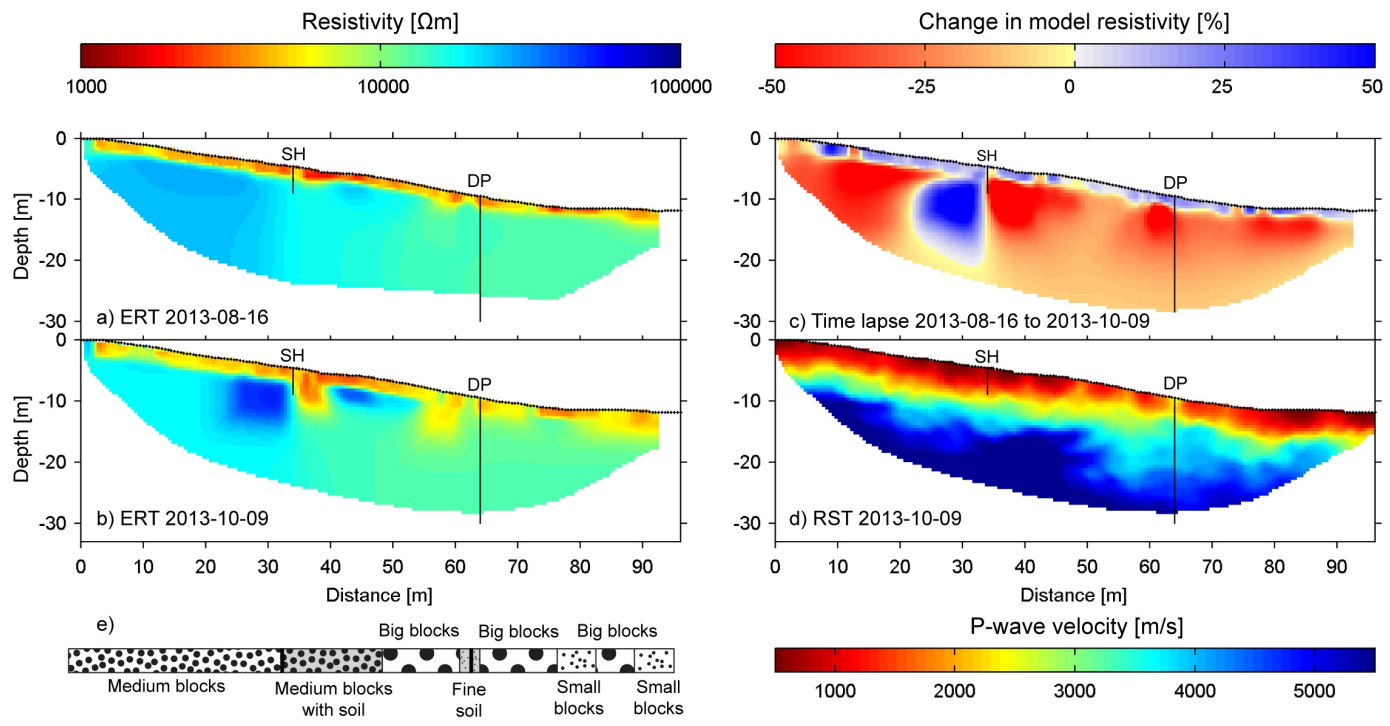

Figure 9. Tomograms of the specific resistivities for both ERT measurements: (a) 16 August 2013, (b) 9 October 2013, (c) percentage change in model resistivity between the two dates and (d) seismic velocities. The location of SH and DP is figured with vertical black lines of respective length. A rough description of the surface aspect along the profile is also shown (e).

bottom of the profile, corresponds to the displacement of the high resistive area observed in the ERT tomograms.

The RST tomogram exhibits much less lateral variations than the ERT results (see Fig. 9d), pointing to the influence of liquid water in the ERT results. One can clearly see a relatively slow layer with velocities between 300 and $1500 \mathrm{~m} \mathrm{~s}^{-1}$ (red and dark red colors) just below the surface, with varying thickness between 3 and $5 \mathrm{~m}$. This layer is thickest in the vicinity of SH and thinnest at DP $(64 \mathrm{~m})$. Below this first layer the velocities increase steadily until reaching the maximum (around $6400 \mathrm{~m} \mathrm{~s}^{-1}$ ). The rate of velocity increase is strongest around $40 \mathrm{~m}$ and there is a clear distinction between the upper part of the profile (until $45 \mathrm{~m}$ ) and the lower one. At depth the high velocity zone is present in the upper part and not in the lower part of the profile. Conversely, the velocities at the surface are much higher in the lower part (especially around DP) than in the upper part.

Both geophysical profiles show clear differences in the subsurface properties as well as surface composition at the borehole locations (Fig. 9e). The upper part of the profile (until $50 \mathrm{~m}$ ) is more or less homogeneously covered by medium size blocks and has the deepest layer of coarse-debris deposits, whereas the granulometry in the lower part is much more variable at the surface and the debris layer is thinner. The boreholes are located in very different conditions: DP is located in-between two zones composed of big blocks (from pluridecimetric to metric), whereas SH is located at the junction between medium size blocks (from pluricentimetric to decimetric), mixed and non-mixed with soil. To relate in detail the results yielded by the geophysics and the measured temperature, the vertical distribution of specific resistivity, seismic velocity and ground temperature at $\mathrm{SH}$ and $\mathrm{DP}$ are shown in Fig. 10.

\section{Discussion}

\subsection{Ground surface temperatures}

In this study both the inter-annual and the spatial variability of MAGST within a restricted area has been analyzed and compared: the results show that at Cime Bianche, the mean range of spatial variability $\left(2.5 \pm 0.1^{\circ} \mathrm{C}\right)$ far exceeds the mean range of observed inter-annual variability $\left(1.6 \pm 0.1^{\circ} \mathrm{C}\right)$. Given the comparatively homogeneous characteristics of the ground surface at the sensors locations, such a variability is essentially caused by the heterogeneity of the snow cover thickness both in space (effect of wind redistribution and micro-morphology) and time (effect of variable weather conditions and precipitations). In particular, the combination of snow cover duration and air temperature during the snow-free period is the main factor controlling MAGST values. This is true not only for snow-free nodes but also for nodes experiencing long-lasting (270 days) yet highly variable (28 days) snow cover.

The thermal effect of snow cover on ground surface temperature has been extensively analyzed (e.g., Goodrich, 1982; Keller and Gubler, 1993; Zhang, 2005; Luetschg et al., 2008; Langer et al., 2013). In recent years, with the advances of minilogger technology, the number of field experiments aimed at the characterization of the spatial variability of GST has grown. Recently Gubler et al. (2011) observed a spatial variability of more than $2.5^{\circ} \mathrm{C}$ within a number of square 


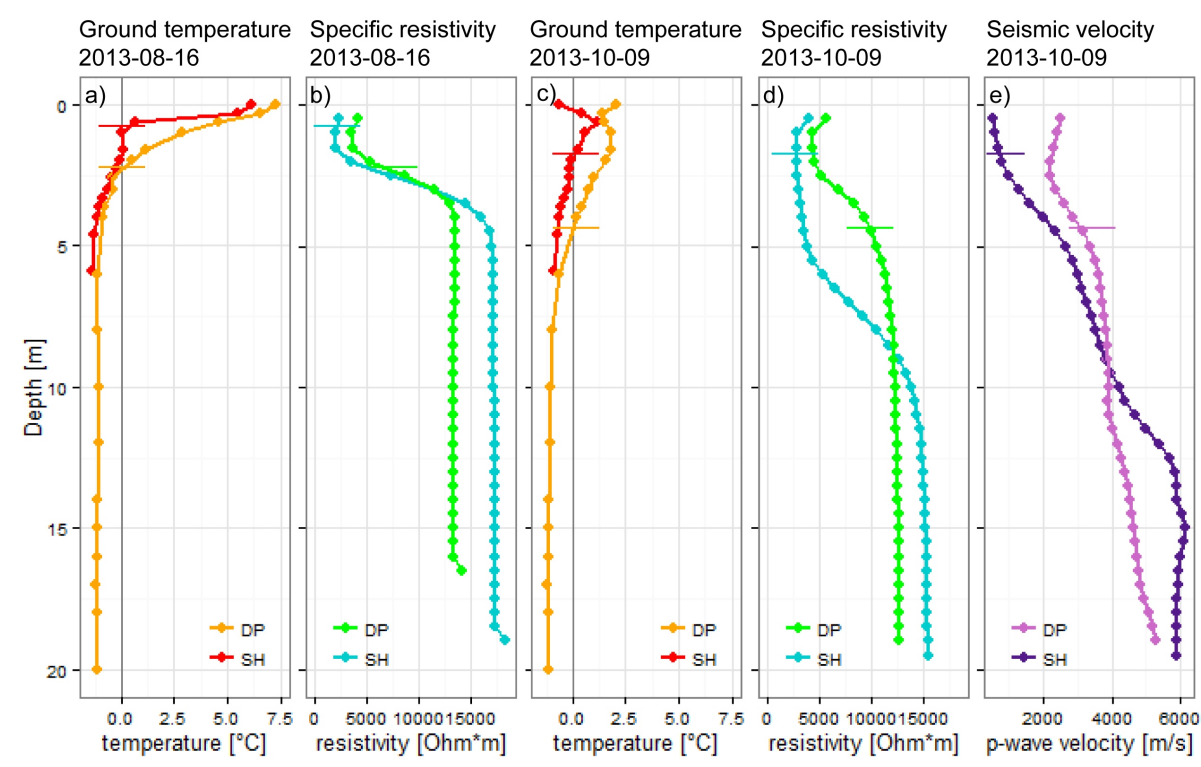

Figure 10. Vertical distribution of specific resistivity and $P$ wave velocity at the borehole locations, extracted from the tomograms shown in Fig. 9, as well as borehole temperatures for the dates of the ERT and RST measurements. The horizontal lines represent the active layer thickness at the respective time periods.

homogeneous areas of $10 \times 10 \mathrm{~m}$. In Norway, Isaksen et al. (2011) report that MAGST varied by $1.5-3.0^{\circ} \mathrm{C}$ over distances of $30-100 \mathrm{~m}$ in a region characterized by mountain permafrost. Rödder and Kneisel (2012) observed ranges exceeding $4.3^{\circ} \mathrm{C}$ between adjacent loggers $(<50 \mathrm{~m})$, although this value includes inhomogeneities of surface characteristics. Similar results were obtained by Gisnås et al. (2014), who observed a variability of the MAGST of up to $6^{\circ} \mathrm{C}$ within heterogeneous areas of $0.5 \mathrm{~km}^{2}$.

The inter-annual variability of MAGST caused by snow is also well known and documented by a number of studies (Romanovsky et al., 2003; Hoelzle et al., 2003; Karunaratne and Burn, 2004; Brenning et al., 2005; Etzelmüller, 2007; Ødegård and Isaksen, 2008; Schneider et al., 2012) but has rarely been explicitly analyzed and quantified. An exception in the Alps is represented by Hoelzle et al. (2003), who reported an inter-annual variability of $\pm 2.7{ }^{\circ} \mathrm{C}$ measured during two seasons on eight mini-loggers with different surface characteristics in the Murtèl-Corvatsch area. Our results thus report a more robust quantification of the mean inter-annual GST variability $\left(1.6 \pm 0.12^{\circ} \mathrm{C}\right)$, based on a longer time series (7 years).

The obtained results are very similar at both measurement depths. Given such a small difference and the agreement of temperature fluctuations between 2 and $30 \mathrm{~cm}$, it is arguable that to describe the spatial variability of GST and run longterm GST observations, measurements at two or more depths are not needed.

\subsection{Active layer}

In this study, both ALT and temperature fluctuations within the active layer of two adjacent boreholes have been compared. Such experimental design provides direct evidence of the small-scale spatial variability of the ALT and allows to evaluate the effect of ice/water content on sub-surface temperature.

From 2009 to 2013 the ALT at Cime Bianche varied within 2.0 and $5.5 \mathrm{~m}$ with a mean inter-annual variability of $1.0 \pm 0.1 \mathrm{~m}$. These ranges and the observed inter-annual variability of ALT are comparable to those recorded in other alpine sites (Anisimov et al., 2002; Christiansen, 2004; Schneider et al., 2012; Smith et al., 2010; PERMOS, 2013) In the Swiss Alps, the thickness of the active layer typically varies between 0.5 and $8 \mathrm{~m}$ depth (Gruber and Haeberli, 2009; PERMOS, 2009, 2013).

ALT in the borehole SH is systematically lower than in DP (mean difference $2.0 \pm 0.1 \mathrm{~m}$ ) even though all the active layer parameters (MAGST, TTOP, THO see Table 1) are very similar between the two boreholes. On one hand, such a similarity suggests that snow cover regimes above the two boreholes are nearly equivalent; thus snow probably plays a major role only on the inter-annual variability of ALT. On the other hand, the pronounced spatial variability of ALT is probably caused by the variability of ice/water content in the sub-surface and associated variation of energy consumption resulting from freezing and melting processes. Langer et al. (2013) confirms this hypothesis by observing, in a tundra lowland landscape, that ALT is related mainly to ground properties (ice content), whereas snow physical 
properties have greatest influence on the ground surface temperatures. Probably the different ice/water content between SH and DP is caused by snowmelt and meltwater infiltration along preferential discontinuities (a borehole acts a discontinuity itself). Hilbich et al. (2008) observed at Schilthorn (Swiss Alps) a similar situation between two boreholes $15 \mathrm{~m}$ apart, ascribing the lower ALT of one borehole to the higher moisture contents (and related freezing) caused by preferential water flow paths from the surrounding slopes. Schneider et al. (2012) analyzed the thermal regime of four adjacent boreholes drilled on differing material (coarse debris, fine debris and bedrock) at Murtèl-Corvatsch (Swiss Alps) and recognized meltwater and ice content as mainly responsible for the observed ALT spatial variability.

The different amount of available water in the active layer of the two boreholes is also reflected by the occurrence of the zero-curtain in the borehole $\mathrm{SH}$ and its absence in the borehole DP. In the upper part of the active layer, a pronounced zero-curtain can be observed two times per year: (i) from snow melt to mid-summer (spring zero-curtain) and (ii) from the snow onset to mid-winter (autumn zero-curtain). Recently, Zenklusen Mutter and Phillips (2012) deeply analyzed similar behaviors on a sample of 10 boreholes in Switzerland, observing that, on average, the duration of the spring zero-curtain is usually shorter than the autumn one and is strongly dependent on snow depth at the end of the winter. At Cime Bianche, such a distinction between spring and autumn zero-curtain is not always possible in the deeper part of the active layer. As also observed by Rist and Phillips (2005), it may happen that, below a certain depth, the ground temperature does not become positive because the energy from the summer heat wave is not sufficient to melt all ice before the onset of the subsequent winter season. This continuous zero-curtain is more probable when a higher amount of meltwater is available (Scherler et al., 2010; Kane et al., 2001) and can occur at a different depth from year to year, strongly influencing the resulting ALT.

\subsection{Permafrost temperature and warming trend}

In order to look for trends that might reflect warming, two non-parametric methods were applied to borehole temperature time series. The detected linear trends are statistically significant (Kendall's $p$ value $<0.01$ ) only at depth below $8 \mathrm{~m}$. Probably, in the first meters, the seasonal and interannual variability of temperatures is so strong that significant trends are not detectable, although a seasonal detrending being applied to remove such high-frequency oscillations (see also Sect. 2.5). The detected trends span the range 0.1$0.01{ }^{\circ} \mathrm{C} \mathrm{yr}^{-1}$, suggesting that at Cime Bianche permafrost is warming.

As also discussed by Zenklusen Mutter et al. (2010), the detection of trends on time series covering a short time span requires caution and adoption of specific criteria. Moreover, the estimation of uncertainties and significance levels is also fundamental for facilitating the comparisons of trends between differing sites and for reproducing trend detection methods on others data sets.

Permafrost warming trends have been observed worldwide, both at high latitude (Harris, 2003; Osterkamp, 2005; Smith et al., 2005; Osterkamp, 2007; Isaksen et al., 2007; Farbrot et al., 2013; Jonsell et al., 2013) and at lower latitude in high mountains (Vonder Mühll, 2001; Harris, 2003; Gruber, 2004; Wu and Zhang, 2008; Phillips and Mutter, 2009; Zenklusen Mutter et al., 2010; PERMOS, 2013; Haeberli, 2013).

Recently in the Alps, Zenklusen Mutter et al. (2010) detected trends on daily temperature time series of two boreholes in the Muot da Barba Peider ridge (Eastern Swiss Alps). For the deep frozen bedrock between 8 and $17.5 \mathrm{~m}$, a general warming trend was found with significant ( $p$ value $<0.05$ ) values ranging from 0.042 to $0.025^{\circ} \mathrm{C} \mathrm{yr}^{-1}$. At Cime Bianche a similar range of warming rate was found between 16 and $20 \mathrm{~m}$. The substantial difference between the two sites is that the Swiss boreholes are drilled at the top of a NW-oriented ridge with a mean slope of $38^{\circ}$ and thus have a strong 3-D thermal effect induced by topography (Noetzli et al., 2007). In the mountains of Scandinavia, Isaksen et al. (2007) reported warming trends between 20 and $60 \mathrm{~m}$ of depth ranging from about 0.05 to $0.005^{\circ} \mathrm{C} \mathrm{yr}^{-1}$ over three sites, while Isaksen et al. (2011) found an increase in mean ground temperature between 6 and $9 \mathrm{~m}$ of depth at two sites, with rates ranging from about 0.015 to $0.095^{\circ} \mathrm{C} \mathrm{yr}^{-1}$. Recently at Tarfala mountain station (Sweden), Jonsell et al. (2013) found trends over 11 years (2001-2011) ranging from 0.047 to $0.002^{\circ} \mathrm{C} \mathrm{yr}^{-1}$ between 20 and $100 \mathrm{~m}$ of depth.

The absolute values of warming rates are difficult to compare because of different site characteristics, geographical regions and methods used for trend detection. Nevertheless, some similitudes exist between our and the above-mentioned case studies: (i) trends are difficult to detect at shallower depth because of the higher seasonal variability of temperatures; (ii) warming trends are mainly significant below 8$10 \mathrm{~m}$ of depth; (iii) warming trends exponentially decrease with depth; (iv) there is no evidence of negative (cooling) trends at any depth in recent literature.

\subsection{Geophysics}

Given the relatively high resistivity and $p$ wave velocities along the profiles, the presence of permafrost observed in the borehole data is confirmed by the geophysics over the whole profile length (Fig. 9). Moreover, a clear discrepancy between the upper part of the profile where SH is located and the lower one with borehole DP can be seen in both the ERT and the RST data.

At DP, the comparatively high $p$ wave velocities indicate the presence of weathered bedrock close to the surface, whereas at SH a layer of coarse-debris deposits in the uppermost $5 \mathrm{~m}$ is confirmed by very low $p$ wave velocities. 
Conversely, $p$ wave velocities at depth are higher for $\mathrm{SH}$ (around $\sim 6000 \mathrm{~m} \mathrm{~s}^{-1}$ ) than for DP (around $\sim 5000 \mathrm{~m} \mathrm{~s}^{-1}$, see also Fig. 10). This difference, also seen in the resistivity data (around $17000 \Omega \mathrm{m}$ at SH and $13000 \Omega \mathrm{m}$ at DP), would indicate that a larger ice content is present in the upslope part of the profile than in the lower part. This is in good agreement with the spatial variation of ALT highlighted in Sect. 3.2 and the zero-curtain phase observed only at SH (see Fig. 6).

The low-resistivity and low-velocity layer near the surface, the thickness of which increases visibly between August and October in the ERT data, is considered to be the active layer. Figure 10 compares the vertical distribution of specific electrical resistivity, $p$ wave velocity and temperature for both boreholes and dates. At first glance, there seems to be a mismatch between resistivity and temperature regarding ALT for $\mathrm{SH}$. However, borehole temperatures at SH in August show constant values at the freezing point between 1 and $3 \mathrm{~m}$ depth (between 2 and $4 \mathrm{~m}$ in October), the deeper level being the depth of the sharply increasing resistivity values. As resistivity is sensitive to the liquid water content, its values will not increase significantly before most of this liquid water has been frozen, coinciding with a temperature increase to values below the freezing point (e.g., Hauck, 2002). Due to the higher water/ice content in SH, this phenomenon ( vertical zero-curtain) is only seen in $\mathrm{SH}$ and not in DP.

The two low resistive areas (34-40 and 53-60 m), already visible in August and more pronounced on the second ERT profile in October, are interpreted as the preferential water flow path. Since the melt water cannot infiltrate through the two ice-rich (high resistive) bodies close by (at 20-33 and $40-52 \mathrm{~m}$ horizontal distances), it is forced to follow a preferential path in-between. The lower infiltration area $(53-60 \mathrm{~m})$ is constrained in the upper part by the ice-rich zone and in the lower part by the presence of bedrock near the surface.

Finally, the displacement of the high resistive area observed near SH (blue zone at depth on the time-lapse tomogram) is most likely an inversion artefact (overcompensation) due to the appearance of the low resistive area in the second ERT profile (cf. Hilbich et al., 2009).

\section{Conclusions}

This paper presents a first synthesis on the thermal state and recent evolution of permafrost in the monitoring site of Cime Bianche, one of the few permanent observatories on the southern side of the European Alps. The analysis focused on (i) the spatial and temporal variability of MAGST in relation to snow cover, (ii) the small-scale $(30 \mathrm{~m})$ spatial variability of ALT and (iii) the warming rate of deep permafrost temperatures. The results of analysis show the following:

1. Spatial variability of MAGST is greater than its interannual variability and is controlled by a combination of air temperature during the snow-free period and snow duration.

2. The ALT at Cime Bianche has a pronounced spatial variability caused mainly by a different ice/water content due to very different surface and subsurface conditions in terms of weathering and fracturing of bedrock.

3. Permafrost at Cime Bianche is warming at significant rates below $8 \mathrm{~m}$ of depth.

\section{The Supplement related to this article is available online at doi:10.5194/tc-9-647-2015-supplement.}

Acknowledgements. This work has been co-funded by a grant from Ev-K2-CNR.

The authors are grateful to the lift company Cervino S.p.a for the continuous logistical support to the research activities at the monitoring site of Cime Bianche.

C. Pellet and C. Hauck gratefully acknowledge a grant from the Swiss National Science Foundation (project SOMOMOUNT No. 200021_143325).

Edited by: J. Boike

\section{References}

Allen, S. K. and Huggel, C.: Extremely warm temperatures as a potential cause of recent high mountain rockfall, Global Planet. Change, 107, 59-69, doi:10.1016/j.gloplacha.2013.04.007, 2013.

Anisimov, O., Shiklomanov, N., and Nelson, F.: Variability of seasonal thaw depth in permafrost regions: a stochastic modeling approach, Ecol. Model., 153, 217-227, doi:10.1016/S03043800(02)00016-9, 2002.

Beltrami, H.: Climate from borehole data: Energy fluxes and temperatures since 1500, Geophys. Res. Lett., 29, 2111, doi:10.1029/2002GL015702, 2002.

Bence, J. R.: Analysis of short time series: correcting for autocorrelation, Ecology, 76, 628-639, 1995.

Bommer, C., Phillips, M., and Arenson, L. U.: Practical recommendations for planning, constructing and maintaining infrastructure in mountain Permafrost, Permafrost Periglac., 21, 97-104, doi:10.1002/ppp.679, 2010.

Brenning, A., Gruber, S., and Hoelzle, M.: Sampling and statistical analyses of BTS measurements, Permafrost Periglac., 16, 383393, doi:10.1002/ppp.541, 2005.

Bronaugh, D., Werner, A., and For the Pacific Climate Impacts Consortium: zyp: Zhang + Yue-Pilon trends package, available at: http://cran.r-project.org/package=zyp (last access: July 2014), 2013.

Burn, C. and Smith, C.: Observations of the "Thermal Offset" in near-surface mean annual ground temperatures at several sites near Mayo, Yukon Territory, Canada, Arctic, 41, 99-104, doi:10.14430/arctic1700, 1988. 
Christiansen, H. H.: Meteorological control on interannual spatial and temporal variations in snow cover and ground thawing in two northeast Greenlandic Circumpolar-Active-LayerMonitoring(CALM) sites, Permafrost Periglac., 15, 155-169, doi:10.1002/ppp.489, 2004.

Christiansen, H. H., Etzelmüller, B., Isaksen, K., Juliussen, H., Farbrot, H., Humlum, O., Johansson, M., Ingeman-Nielsen, T., Kristensen, L., Hjort, J., and Others, A.: The thermal state of permafrost in the nordic area during the international polar year 2007-2009, Permafrost Periglac., 21, 156-181, doi:10.1002/ppp.687, 2010.

Cleveland, R., Cleveland, W., McRae, J. E., and Terpenning, I.: STL: A seasonal-trend decomposition procedure based on loess, J. Official Stat., 6, 3-73, 1990.

Cleveland, W.: Robust locally weighted regression and smoothing scatterplots, J. Am. Stat. Assoc., 74, 829-836, doi:10.1080/01621459.1979.10481038, 1979.

Cremonese, E., Gruber, S., Phillips, M., Pogliotti, P., Boeckli, L., Noetzli, J., Suter, C., Bodin, X., Crepaz, A., Kellerer-Pirklbauer, A., Lang, K., Letey, S., Mair, V., Morra di Cella, U., Ravanel, L., Scapozza, C., Seppi, R., and Zischg, A.: Brief Communication: "An inventory of permafrost evidence for the European Alps", The Cryosphere, 5, 651-657, doi:10.5194/tc-5-651-2011, 2011.

Dal Piaz, G. V.: Le Alpi dal M. Bianco al Lago Maggiore: 13 Itinerari Automobilistici e 97 Escursioni a Piedi, Vol. 1, Seven Hills Books, Padova, Italy, 1992.

Etzelmüller, B.: The regional distribution of mountain permafrost in Iceland, Permafrost Periglac., 199, 185-199, doi:10.1002/ppp.583, 2007.

Etzelmüller, B.: Recent advances in mountain permafrost research, Permafrost Periglac., 24, 99-107, doi:10.1002/ppp.1772, 2013.

Evans, I. S. and Cox, N. J.: Global variations of local asymmetry in glacier altitude: separation of north-south and east-west components, J. Glaciol., 51, 469-482, 2005.

Farbrot, H., Isaksen, K., Etzelmüller, B., and Gisnås, K.: Ground thermal regime and permafrost distribution under a changing climate in Northern Norway, Permafrost Periglac., 24, 20-38, doi:10.1002/ppp.1763, 2013.

Fischer, L., Purves, R. S., Huggel, C., Noetzli, J., and Haeberli, W.: On the influence of topographic, geological and cryospheric factors on rock avalanches and rockfalls in high-mountain areas, Nat. Hazards Earth Syst. Sci., 12, 241-254, doi:10.5194/nhess12-241-2012, 2012.

Fischer, L., Huggel, C., Kääb, A., and Haeberli, W.: Slope failures and erosion rates on a glacierized high-mountain face under climatic changes, Earth Surf. Proc. Land., 38, 836-846, doi:10.1002/esp.3355, 2013.

Frei, C. and Schär, C.: A precipitation climatology of the alps from high-resolution rain-gauge observations, Int. J. Climatol., 18, 873-900, 1998.

Geotomosoft: Res2dinv software Tutorial: 2-D and 3-D electrical imaging surveys, available at: www.geotomosoft.com, last access: July 2014.

Gisnås, K., Westermann, S., Schuler, T. V., Litherland, T., Isaksen, K., Boike, J., and Etzelmüller, B.: A statistical approach to represent small-scale variability of permafrost temperatures due to snow cover, The Cryosphere, 8, 2063-2074, doi:10.5194/tc-82063-2014, 2014.
Gocic, M. and Trajkovic, S.: Analysis of changes in meteorological variables using Mann-Kendall and Sen's slope estimator statistical tests in Serbia, Global Planet. Change, 100, 172-182, doi:10.1016/j.gloplacha.2012.10.014, 2013.

Goodrich, L. E.: The influence of snow cover on the ground thermal regime, Can. Geotech. J., 19, 421-432, doi:10.1139/t82-047, 1982.

Gruber, S.: Permafrost thaw and destabilization of Alpine rock walls in the hot summer of 2003, Geophys. Res. Lett., 31, L13504, doi:10.1029/2004GL020051, 2004.

Gruber, S. and Haeberli, W.: Permafrost in steep bedrock slopes and its temperature related destabilization following climate change, J. Geophys. Res.-Earth, 112, F02S18, doi:10.1029/2006JF000547, 2007.

Gruber, S. and Haeberli, W.: Mountain permafrost, in: Permafrost Soils, Springer, Innsbruck, Austria, 33-44, doi:10.1007/978-3540-69371-0, 2009.

Gruber, S. and Hoelzle, M.: The cooling effect of coarse blocks revisited: a modeling study of a purely conductive mechanism, in: Proceedings of the 9th International Conference on Permafrost, 29 June-3 July 2008, Fairbanks, Alaska, USA, 557-561, 2008.

Gubler, S., Fiddes, J., Keller, M., and Gruber, S.: Scaledependent measurement and analysis of ground surface temperature variability in alpine terrain, The Cryosphere, 5, 431-443, doi:10.5194/tc-5-431-2011, 2011.

Guglielmin, M.: Ground surface temperature (GST), active layer and permafrost monitoring in continental Antarctica, Permafrost Periglac., 17, 133-143, doi:10.1002/ppp.553, 2006.

Guglielmin, M. and Cannone, N.: A permafrost warming in a cooling Antarctica?, Climatic Change, 111, 177-195, doi:10.1007/s10584-011-0137-2, 2012.

Guglielmin, M. and Vannuzzo, C.: Studio della distribuzione del permafrost e delle relazioni con i ghiacciai della piccola età glaciale nell'alta valtournenche (Valle d'Aosta, Italia), Atti Ticinesi di Scienze della Terra, 38, 119-127, 1995.

Guglielmin, M., Aldighieri, B., and Testa, B.: PERMACLIM: a model for the distribution of mountain permafrost, based on climatic observations, Geomorphology, 51, 245-257, doi:10.1016/S0169-555X(02)00221-0, 2003.

Guglielmin, M., Dalle Fratte, M., and Cannone, N.: Permafrost warming and vegetation changes in continental Antarctica, Environ. Res. Lett., 9, 045001, doi:10.1088/1748-9326/9/4/045001, 2014a.

Guglielmin, M., Worland, M. R., Baio, F., and Convey, P.: Permafrost and snow monitoring at Rothera Point (Adelaide Island, Maritime Antarctica): implications for rock weathering in cryotic conditions, Geomorphology, 225, 47-56, doi:10.1016/j.geomorph.2014.03.051, 2014b.

Haeberli, W.: Mountain permafrost research frontiers and a special long-term challenge, Cold Reg. Sci. Technol., 96, 71-76, doi:10.1016/j.coldregions.2013.02.004, 2013.

Haeberli, W., Noetzli, J., Arenson, L. U., Delaloye, R., GärtnerRoer, I., Gruber, S., Isaksen, K., Kneisel, C., Krautblatter, M., and Phillips, M.: Mountain permafrost: development and challenges of a young research field, J. Glaciol., 56, 1043-1058, doi:10.3189/002214311796406121, 2010.

Hamed, K.: Enhancing the effectiveness of prewhitening in trend analysis of hydrologic data, J. Hydrol., 368, 143-155, doi:10.1016/j.jhydrol.2009.01.040, 2009. 
Harris, C.: Warming permafrost in European mountains, Global Planet. Change, 39, 215-225, doi:10.1016/j.gloplacha.2003.04.001, 2003.

Harris, C. and Haeberli, W.: Permafrost monitoring in the high mountains of Europe: the PACE project in its global context, Permafrost Periglac., 11, 3-11, doi:10.1002/ppp.377, 2001.

Harris, C., Arenson, L. U., Christiansen, H. H., Etzelmüller, B., Frauenfelder, R., Gruber, S., Haeberli, W., Hauck, C., Hölzle, M., Humlum, O., Isaksen, K., Kääb, A., Kern-Lütschg, M., Lehning, M., Matsuoka, N., Murton, J., Nötzli, J., Phillips, M., Ross, N., Seppälä, M., Springman, S., and Vonder Mühll, D.: Permafrost and climate in Europe: monitoring and modelling thermal, geomorphological and geotechnical responses, Earth-Sci. Rev., 92, 117-171, doi:10.1016/j.earscirev.2008.12.002, 2009.

Hauck, C.: Frozen ground monitoring using DC resistivity tomography, Geophys. Res. Lett., 29, 12-1-12-4, doi:10.1029/2002GL014995, 2002.

Helsel, D. R. and Hirsch, R. M.: Trend analysis, in: Statistical Methods in Water Resources, chap. 12, Elsevier, Amsterdam, Holland, 1992.

Hilbich, C., Hauck, C., Hoelzle, M., Scherler, M., Schudel, L., Völksch, I., Vonder Mühll, D., and Mäusbacher, R.: Monitoring mountain permafrost evolution using electrical resistivity tomography: a 7-year study of seasonal, annual, and long-term variations at Schilthorn, Swiss Alps, J. Geophys. Res., 113, F01S90, doi:10.1029/2007JF000799, 2008.

Hilbich, C., Marescot, L., Hauck, C., Loke, M.H. and Mäusbacher, R.: Applicability of Electrical Resistivity Tomography Monitoring to coarse blocky and ice-rich permafrost landforms, Permafrost Periglac., 20, 269-284, 2009.

Hipp, T., Etzelmüller, B., and Westermann, S.: Permafrost in Alpine Rock faces from Jotunheimen and Hurrungane, Southern Norway, Permafrost Periglac., 25, 1-13, doi:10.1002/ppp.1799, 2014.

Hoelzle, M., Haeberli, W., and Stocker-Mittaz, C.: Miniature ground temperature data logger measurements 2000-2002 in the Murtèl-Corvatsch area, Eastern Swiss Alps, in: Proceedings of the 8th International Conference on Permafrost, 1, 7-12, available at: http://www.geo.uzh.ch/ hoelzle/hoelzleetal2003b. pdf (last access: July 2014), 2003.

Isaksen K., Holmlund, P., Sollid, J. L., and Harris, C.: Three deep alpine-permafrost boreholes in svalbard and scandinavia, Permafrost Periglac., 12, 13-25, 2001.

Isaksen, K., Sollid, J. L., Holmlund, P., and Harris, C.: Recent warming of mountain permafrost in Svalbard and Scandinavia, J. Geophys. Res., 112, F02S04, doi:10.1029/2006JF000522, 2007.

Isaksen, K., Ødegård, R. S., Etzelmüller, B., Hilbich, C., Hauck, C., Farbrot, H., Eiken, T., Hygen, H. O., and Hipp, T. F.: Degrading mountain permafrost in Southern Norway: spatial and temporal variability of mean ground temperatures, 1999-2009, Permafrost Periglac., 22, 361-377, doi:10.1002/ppp.728, 2011.

Jonsell, U., Hock, R., and Duguay, M.: Recent air and ground temperature increases at Tarfala Research Station, Sweden, Polar Res., 1, 1-11, available at: http://www.polarresearch.net/index. php/polar/article/view/19807 (last access: July 2014), 2013.

Kane, D. L., Hinkel, K. M., Goering, D. J., Hinzman, L. D., and Outcalt, S. I.: Non-conductive heat transfer associated with frozen soils, Global Planet. Change, 29, 275-292, doi:10.1016/S0921-8181(01)00095-9, 2001.
Karunaratne, K. C. and Burn, C. R.: Relations between air and surface temperature in discontinuous permafrost terrain near Mayo, Yukon Territory, Can. J. Earth Sci., 1451, 1437-1451, doi:10.1139/E04-082, 2004.

Keller, F.: Automated mapping of mountain permafrost using the program PERMAKART within the geographical information system ARC/INFO, Permafrost Periglac., 3, 133-138, doi:10.1002/ppp.3430030210, 1992.

Keller, F. and Gubler, H. U.: Interaction between snow cover and high mountain permafrost, Murtel-Corvatsch, Swiss Alps, in: vol. 1, Proceedings of the Sixth International Conference on Permafrost, Beijing, 21-25 July, Zurich, Switzerland, 332-337, 1993.

Kendall, M. G.: Rank Correlation Methods, Griffin, Oxford, England, 1948.

Kousari, M. R., Ahani, H., and Hendi-zadeh, R.: Temporal and spatial trend detection of maximum air temperature in Iran during 1960-2005, Global Planet. Change, 111, 97-110, doi:10.1016/j.gloplacha.2013.08.011, 2013.

Langer, M., Westermann, S., Heikenfeld, M., Dorn, W., and Boike, J.: Satellite-based modeling of permafrost temperatures in a tundra lowland landscape, Remote Sens. Environ., 135, 1224, doi:10.1016/j.rse.2013.03.011, 2013.

Luetschg, M., Lehning, M., and Haeberli, W.: A sensitivity study of factors influencing warm/thin permafrost in the Swiss Alps, J. Glaciol., 54, 696-704, doi:10.3189/002214308786570881, 2008.

Mann, H. B.: Nonparametric tests against trend, Econometrics, 13, 245-259, 1945.

Mercalli, L. and Cat Berro, D.: Atlante Climatico Della Valle d'Aosta, Vol. 2, SMS, Oxford, England, 2003.

Noetzli, J. and Gruber, S.: Transient thermal effects in Alpine permafrost, The Cryosphere, 3, 85-99, doi:10.5194/tc-3-85-2009, 2009.

Noetzli, J., Gruber, S., Kohl, T., Salzmann, N., and Haeberli, W.: Three-dimensional distribution and evolution of permafrost temperatures in idealized high-mountain topography, J. Geophys. Res., 112, F02S13, doi:10.1029/2006JF000545, 2007.

Ødegård, R. and Isaksen, K.: MAGST in mountain permafrost, Dovrefjell, southern Norway, 2001-2006, in: Proceedings of the 9th International Conference on Permafrost, 1311-1315, available at: https://www.matnat.uio.no/geo/english/research/ projects/cryolink/publications/NICOPoedegaardetal.pdf (last access: July 2014), 2008.

Osterkamp, T. E.: The recent warming of permafrost in Alaska, Global Planet. Change, 49, 187-202, doi:10.1016/j.gloplacha.2005.09.001, 2005.

Osterkamp, T. E.: Characteristics of the recent warming of permafrost in Alaska, J. Geophys. Res., 112, F02S02, doi:10.1029/2006JF000578, 2007.

PERMOS: Permafrost in Switzerland 2004/2005 and 2005/2006, Glaciological Report Permafrost No. 6/7, Tech. Rep. 6, Cryospheric Commission of the Swiss Academy of Sciences, Zurich, Switzerland, 2009.

PERMOS: Permafrost in Switzerland 2008/2009 and 2009/2010, Glaciological Report Permafrost No. 10/11, Tech. Rep. 10, Cryospheric Commission of the Swiss Academy of Sciences, Zurich, Switzerland, 2013. 
Phillips, M. and Mutter, E.: Rapid degradation of ground ice in a ventilated talus slope: fluiela Pass, Swiss Alps, Permafrost Periglac., 14, 1-14, doi:10.1002/ppp.638, 2009.

Pogliotti, P.: Influence of Snow Cover on MAGST over Complex Morphologies in Mountain Permafrost Regions, $\mathrm{PhD}$ thesis, University of Turin, Turin, Italy, 2010.

R Core Team: R: A Language and Environment for Statistical Computing, R Foundation for Statistical Computing, Vienna, Austria, available at: http://www.r-project.org/, last access: July 2014.

Rist, A. and Phillips, M.: First results of investigations on hydrothermal processes within the active layer above alpine permafrost in steep terrain, Norsk Geogr. Tidsskr., 59, 177-183, doi:10.1080/00291950510020574, 2005.

Rödder, T. and Kneisel, C.: Influence of snow cover and grain size on the ground thermal regime in the discontinuous permafrost zone, Swiss Alps, Geomorphology, 175-176, 176-189, doi:10.1016/j.geomorph.2012.07.008, 2012.

Romanovsky, V. E., Burgess, M., Smith, S., Yoshikawa, K., and Brown, J.: Permafrost temperature records: indicators of climate change, EOS T. Am. Geophys. Un., 83, 589, doi:10.1029/2002EO000402, 2002.

Romanovsky, V. E., Sergueev, D. O., and Osterkamp, T. E.: Temporal variations in the active layer and near-surface permafrost temperatures at the long-term observatories in northern Alaska, Month, 8, Proceedings of the 8th International Conference on Permafrost, 21-25 July, Zurich, Switzerland, 2003.

Romanovsky, V. E., Drozdov, D. S., Oberman, N. G., Malkova, G. V., Kholodov, A. L., Marchenko, S. S., Moskalenko, N. G., Sergeev, D. O., Ukraintseva, N. G., Abramov, A., Gilichinsky, D., and Vasiliev, A. A.: Thermal state of permafrost in Russia, Permafrost Periglac., 21, 136-155, doi:10.1002/ppp.683, 2010.

Sandmeier: ReflexW Scientific Software, Sandmeier geophysical research, available at: www.sandmeier-geo.de, last access: 2 April 2015, Karlsruhe, Germany, 2014.

Scherler, M., Hauck, C., Hoelzle, M., Stähli, M., and Völksch, I.: Meltwater infiltration into the frozen active layer at an alpine permafrost site, Permafrost Periglac., 21, 325-334, doi:10.1002/ppp.694, 2010.

Schmid, M.-O., Gubler, S., Fiddes, J., and Gruber, S.: Inferring snowpack ripening and melt-out from distributed measurements of near-surface ground temperatures, The Cryosphere, 6, 11271139, doi:10.5194/tc-6-1127-2012, 2012.

Schneider, S., Hoelzle, M., and Hauck, C.: Influence of surface and subsurface heterogeneity on observed borehole temperatures at a mountain permafrost site in the Upper Engadine, Swiss Alps, The Cryosphere, 6, 517-531, doi:10.5194/tc-6-517-2012, 2012.

Sen, P. K.: Estimates of the regression coefficient based on Kendall's tau, J. Am. Stat. Assoc., 63, 1379-1389, doi:10.1080/01621459.1968.10480934, 1968.

Smith, M. and Riseborough, D.: Permafrost monitoring and detection of climate change, Permafrost Periglac., 7, 301-309, 1996.
Smith, S. L., Burgess, M., Riseborough, D., and Mark Nixon, F. Recent trends from Canadian permafrost thermal monitoring network sites, Permafrost Periglac., 16, 19-30, doi:10.1002/ppp.511, 2005.

Smith, S. L., Romanovsky, V. E., Lewkowicz, A. G., Burn, C. R., Allard, M., Clow, G., Yoshikawa, K., and Throop, J.: Thermal state of permafrost in North America: a contribution to the international polar year, Permafrost Periglac., 21, 117-135, doi:10.1002/ppp.690, 2010.

Springman, S. and Arenson, L. U.: Recent advances in permafrost geotechnics, in: Proceedings of the 9th International Conference on Permafrost, 29 June-3 July 2008, Fairbanks, Alaska, USA, 1685-1694, 2008.

Stoffel, M., Tiranti, D., and Huggel, C.: Climate change impacts on mass movements - case studies from the European Alps, Sci. Total Environ., 493, 1255-1266, doi:10.1016/j.scitotenv.2014.02.102, 2014.

van Everdingen, R. O.: Multi-language glossary of permafrost and related ground-ice terms, Tech. rep., International Permafrost Association, Boulder, Colorado, available at: https://nsidc.org/fgdc/ glossary/ (last access: July 2014), 2005.

von Storch, H. and Navarra, A.: Analysis of climate variability: applications of statistical techniques, Springer, Berlin, Germany, 1999.

Vonder Mühll, D.: Thermal variations of mountain permafrost: an example of measurements since 1987 in the Swiss Alps, in: Global Change and Protected Areas, Springer Netherlands, 8395, 2001.

Wollschläger, U., Gerhards, H., Yu, Q., and Roth, K.: Multi-channel ground-penetrating radar to explore spatial variations in thaw depth and moisture content in the active layer of a permafrost site, The Cryosphere, 4, 269-283, doi:10.5194/tc-4-269-2010, 2010.

Wright, N., Hayashi, M., and Quinton, W. L.: Spatial and temporal variations in active layer thawing and their implication on runoff generation in peat-covered permafrost terrain, Water Resour. Res., 45, W05414, doi:10.1029/2008WR006880, 2009.

$\mathrm{Wu}, \mathrm{Q}$. and Zhang, T.: Recent permafrost warming on the Qinghai-Tibetan Plateau, J. Geophys. Res., 113, D13108,doi:10.1029/2007JD009539, 2008.

Zenklusen Mutter, E. and Phillips, M.: Active layer characteristics at ten borehole sites in Alpine permafrost terrain, Switzerland, Permafrost Periglac., 23, 138-151, doi:10.1002/ppp.1738, 2012.

Zenklusen Mutter, E., Blanchet, J., and Phillips, M.: Analysis of ground temperature trends in Alpine permafrost using generalized least squares, J. Geophys. Res., 115, F04009, doi:10.1029/2009JF001648, 2010.

Zhang, T.: Influence of the seasonal snow cover on the ground thermal regime: an overview, Rev. Geophys., 43, RG4002, doi:10.1029/2004RG000157, 2005. 